\title{
FURTHER STUDIES OF THE GAMMA-RELATED PROTEINS OF NORMAL URINE
}

\author{
By G. T. STEVENSON *
}

(From the Departments of Medicine and Biochemistry, The University of Sydney, Australia)

(Submitted for publication August 22, 1961 ; accepted January 5, 1962)

The designation "gamma-related" will be applied to any protein antigenically related to-i.e., reacting with antiserum prepared against-human plasma $\gamma$-globulins.

Webb, Rose and Sehon (1) and Franklin (2) have described the urinary proteins of $\gamma$-electrophoretic mobility. They found that these consisted largely of material of lower molecular weight than, but antigenically related to, the 7S $\gamma$-globulin of plasma. The protein population described in these two papers overlaps that defined in this and a previous paper (3) by its antigenic characteristics. It has been decided to continue the interim definition based on antigenic properties for several reasons. First, it permits a ready and probably significant delineation of the group of proteins. Next, as will be shown, not all of the $\gamma$-related proteins are of $\gamma$-electrophoretic mobility, and much of the urinary protein of $\gamma$-electrophoretic mobility is not $\gamma$-related.

The urinary $\gamma$-protein, defined by either electrophoretic or antigenic criteria, is divisible into two fractions $(2,3)$ : one of higher molecular weight, and apparently identical with plasma $7 \mathrm{~S} \gamma$-globulin; the other of lower molecular weight. $\mathrm{Re}$ semblances between the latter and Bence Jones proteins have been described (3).

The present paper reports further investigations of the low molecular weight $\gamma$-related protein of urine. This will be referred to as " $\gamma$ - $\mathbf{u}$ protein." It is further compared with Bence Jones proteins, it is tentatively identified in normal serum and cerebrospinal fluid, and it is shown that it is probably not merely a breakdown product of larger plasma $\gamma$-globulin molecules.

* In receipt of a grant from the Postgraduate Medical Foundation, The University of Sydney. Present address: Department of Biochemistry, University of Oxford, England. Address requests for reprints to the Department of Medicine, The University of Sydney.

\section{METHODS}

Ultrafiltration, biuret estimations of protein, and immunochemical procedures were performed as previously described (3). Ammonium sulfate saturations are referred to $4^{\circ} \mathrm{C}$. Ultracentrifugal analyses were carried out in the Spinco model $\mathrm{E}$ apparatus; sedimentation velocities were calculated as described by Schachman (4). Radioactive assays of $I^{131}$ employed a well-type scintillation counter.

Antiserum to plasma $\gamma$-globulins (anti-II serum) was prepared by injecting rabbits intravenously with alumprecipitated Cohn fraction II (Commonwealth Serum Laboratories, Australia), as recommended by Kabat and Mayer (5). The animals were bled after both primary and secondary courses. All sera containing a satisfactory level of antibody to one or the other antigenic type of Bence Jones protein were pooled. (Not all the animals produced appreciable antibody to Bence Jones determinants of the $\gamma$-globulins.) Immunoelectrophoresis revealed no antibody to serum proteins other than $\gamma$-related protein.

A collection of 14 Bence Jones proteins was available for comparison with $\boldsymbol{\gamma}-\mathbf{u}$ protein. In accord with the findings of previous authors (6-8), these were divisible into two distinct antigenic types on the basis of their reactions with rabbit antisera to plasma $\gamma$-globulins or to Bence Jones proteins themselves. One protein of each type was used in obtaining results presented in this paper. Each was prepared from urine by ammonium sulfate precipitation and further purified by ethanol precipitation. Conditions pertaining for the latter were: ethanol 30 per cent, $\mathrm{pH} 6.9$, ionic strength 0.15 , temperature $-10^{\circ} \mathrm{C}$, protein concentration about 2 per cent. In order to remove the $7 \mathrm{~S} \gamma$-globulin or serum myeloma protein often present in small amounts in ammonium sulfate preparations, the addition of ethanol was interrupted after the first appearance of turbidity, and this initial precipitate was discarded. Both the final preparations were homogeneous by analytical ultracentrifugation and moving boundary electrophoresis. This implies, in particular, that their solutions could have been contaminated with only negligible amounts of normal urinary proteins.

Preparation of $\gamma$-related proteins from normal urine. Pooled or individual urines were collected from laboratory staff. Thimerosal was added to 0.01 per cent and any deposit removed. After a 24-hour volume had been concentrated to 30 to $50 \mathrm{ml}$ by ultrafiltration, it was dialyzed against $0.15 \mathrm{M} \mathrm{NaCl}$ and then against saturated ammonium sulfate, precipitating the proteins. The part 
of the precipitate that dissolved in $3 \mathrm{ml}$ of $0.04 \mathrm{M}, \mathrm{pH}$ 6.0 , phosphate buffer was dialyzed against this until free of ammonium ion, and next passed into a diethylaminoethyl (DEAE)-cellulose column (0.8 $\mathrm{g}$ Whatman $\mathrm{DE}$ 50 powder in a column $13 \mathrm{~cm}$ long, $1 \mathrm{~cm}$ diameter), previously equilibrated with the same buffer. The $\gamma$-related proteins were then eluted with $25 \mathrm{ml}$ of the buffer. Each stage of the preparation yielded a high recovery of these proteins.

Some $\gamma$-electrophoretic fractions of the total urinary protein were also obtained, by agar gel and starch block methods (9). Yields of $\gamma$-related proteins were lower than in the DEAE-cellulose effluents, apparently because the latter included the electrophoretically faster of these proteins.

Attempts to purify further and to fractionate the $\gamma$-related proteins had limited success. The chief difficulty was the wide range of physicochemical properties shown by these substances. While it was possible (by ammonium sulfate precipitation or gradient elution from DEAEcellulose) to obtain considerable purification of $7 \mathrm{~S}$ $\gamma$-globulin or $\gamma$-u protein, the yield was always poor, and the preparations had to be regarded as biased by the very exclusion of much of the relevant protein population. For immunochemical studies requiring $\gamma-\mathrm{u}$ protein essentially free of $7 \mathrm{~S} \gamma$-globulin, the latter was removed (with loss of some $\gamma$-u protein) by precipitating the column effluent with 0.4 saturated ammonium sulfate at $\mathrm{pH}$ 6.5 ; the bulk of the remaining $\gamma$-u protein was then precipitated with 0.55 saturated ammonium sulfate at $\mathrm{pH}$ 5.0. The amount of $\gamma-\mathrm{u}$ protein in this preparation was estimated from the total protein content and the proportion of radioactivity, precipitable by anti-II serum, after the proteins had been labeled with $\mathrm{I}^{131}$. It could then be used for construction of rough quantitative precipitin curves.

Normal serum was collected in the usual manner. Samples from two subjects were examined individually and gave the same results.

Cerebrospinal fuid (CSF) was obtained from two sources: 1) samples sent to a clinical laboratory, found to be normal, and pooled; 2) $100 \mathrm{ml}$ removed from a patient undergoing pneumoencephalography, which was also biochemically normal. The samples were dialyzed against polyvinylpyrrolidone to a 10 to $20 \times$ concentration. Results for both lots were the same.

Fractionation of serum and cerebrospinal fluid. In order to obtain their low molecular weight proteins in increased relative concentration, serum and CSF were passed through a column of dextran gel (Sephadex G-75, Pharmacia, Sweden) (10). A column of $3-\mathrm{cm}$ diameter was packed to a height of $18 \mathrm{~cm}$ by free flow. Untreated serum or concentrated CSF was allowed to enter and was eluted with $0.15 \mathrm{M}, \mathrm{pH} 7.4$, phosphate buffer. The void volume was estimated by allowing the effluent to drop into 40 per cent trichloroacetic acid (TCA) until turbidity first appeared. The subsequent effluent was monitored as described later.

Radioiodination of protein, using carrier-free $\mathrm{I}^{18 \mathbf{1}}$ (Amersham), was carried out essentially as described by
Talmage, Baker and Akeson (11). The solution was then passed through a dextran gel column (Sephadex G-25) to remove free iodide. More than 98 per cent of radioactivity in final protein solutions could be precipitated by cold TCA. (This does not apply after labeling of the urinary DEAE-cellulose or electrophoretic preparations, since these contained protein not precipitated by TCA.)

In vivo study of $I^{131}$-labeled plasma $\gamma$-globulins. In an experiment designed to assess the possibility of $\gamma$-u protein deriving from larger plasma $\gamma$-globulin molecules, radioiodinated plasma globulins were injected intravenously into two healthy adult males. Cohn fraction II (predominantly $7 \mathrm{~S} \boldsymbol{\gamma}$-globulin) was iodinated as described above. In order to minimize the amount of any contaminating low molecular weight protein in the final preparation, the solution was passed through a Sephadex G-75 column and only the first half of protein in the effluent was utilized. Free iodide was removed as effectively as by Sephadex G-25. The final solution was Seitz-filtered, and immediately $30 \mathrm{mg}$ of protein, containing about $60 \mu \mathrm{c}$ of $\mathrm{I}^{131}$, was injected. Urine was collected in two lots: that passed from 25 to 72 , and that from 73 to 120 hours, inclusive, after injection. The urines were concentrated by ultrafiltration and the proteins precipitated as previously described. Precipitates were washed with saturated ammonium sulfate solution until the washings were free of radioactivity. Subsequent treatment of the precipitates is described later.

\section{RESULTS}

Characterization of urinary $\gamma$-related proteins. About $16 \mathrm{mg}$ protein per 24-hour urinary output was contained in the DEAE-cellulose effluents. This appeared to consist of 7S $\gamma$-globulin, $\gamma$-u protein, and protein not $\gamma$-related. No serum protein other than $\gamma$-related protein was detectable by a precipitin reaction using Pasteur horse antiserum to human serum.

Three lots of DEAE-cellulose effluent and two lots of urinary protein of $\gamma$-electrophoretic mobility (prepared in agar gel) were labeled with $\mathrm{I}^{131} ; 25$ to 40 per cent of the radioactivity of these solutions could be precipitated by anti-II serum. As estimated by the biuret method, the maximal amount of protein precipitable by the antiserum was not altered by the iodination procedure. Nor was there evidence of extensive formation of soluble antigen-antibody complexes, since rabbit $\gamma$-globulins precipitated from the supernatants by 0.36 saturated ammonium sulfate showed little radioactivity. In two solutions of serum proteins of $\gamma$-electrophoretic mobility, prepared and labeled as were the urinary proteins, 86 and 91 per cent of 


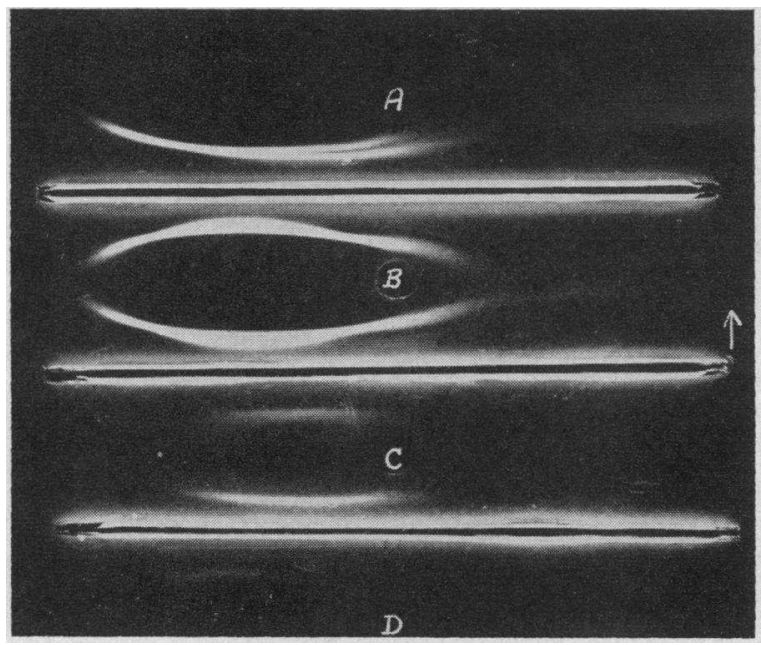

Fig. 1. Electrophoretic DISTRIbUtion OF GAMMaRELATED PROTEINS IN DEAE-CELlulose efFluent. AntiII serum in all troughs. Wells: A, DEAE-cellulose effluent; $B$, normal serum; C, $\gamma-\mathbf{u}$ protein; D, a Bence Jones protein. The arrow marks the position to which albumin migrated.

the radioactivity was precipitable by antiserum. It therefore appears that, in contrast to what pertains in plasma, much of the urinary protein of
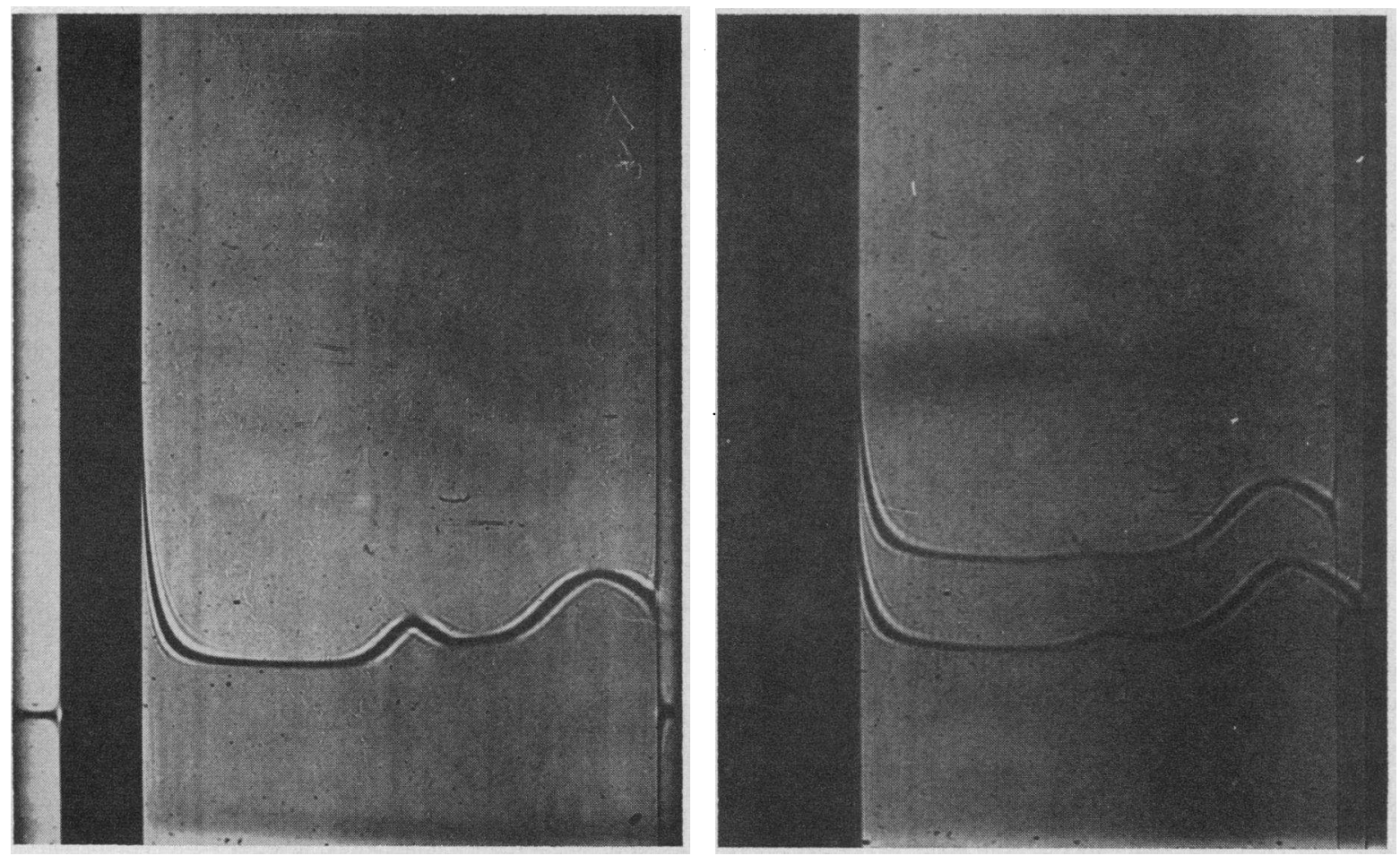

Fig. 2. Ultracentrifugal patterns of three lots of DEAE-Cellulose effluent. Variation in the patterns obtained is apparent. Both photographs after 72 minutes at $59,780 \mathrm{rpm}$; sedimentation is proceeding toward the left. 


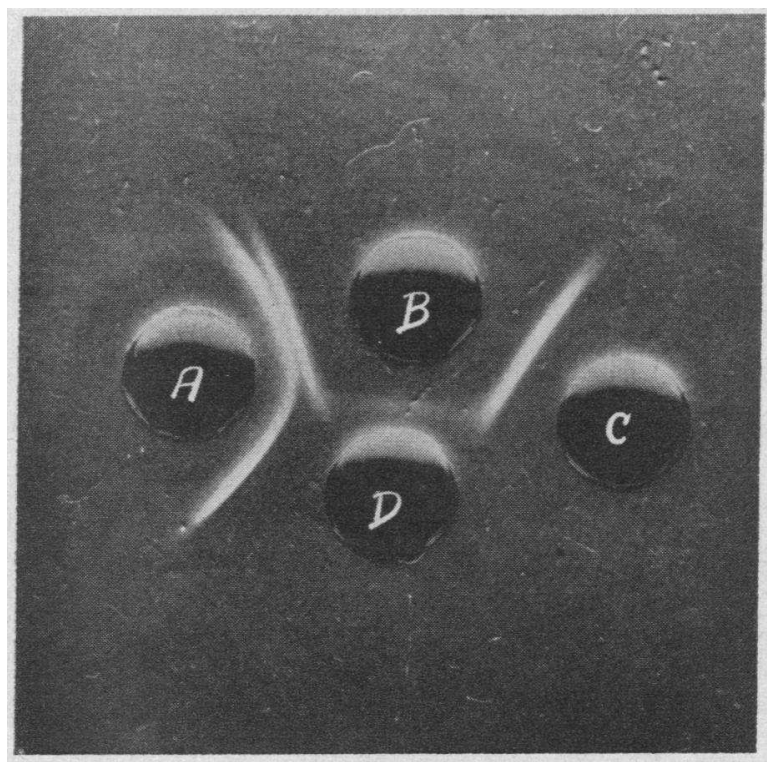

Fig. 3. REACtIONS OF URINARY PROTEINS WITH ANTI-II SERUM. Wells: A, anti-II serum; B, urinary proteins; $\mathrm{C}$, anti-II serum absorbed at the equivalence zones with both antigenic types of Bence Jones proteins recognized by this antiserum; $D$, supernatant obtained after mixing (under conditions of antibody excess) urinary proteins with the partially absorbed antiserum used in well $\mathrm{C}$. Between wells $\mathrm{A}$ and $\mathrm{B}$ are bands of precipitate due to $7 \mathrm{~S} \gamma$-globulin (the straight band) and $\gamma$-u protein (the curved band). Between wells $B$ and $C$ only a $7 \mathrm{~S} \gamma$-band has formed. No precipitate has formed between wells $\mathrm{D}$ and $\mathrm{C}$, indicating that all $7 \mathrm{~S} \gamma$-globulin has previously been precipitated from the contents of well $D$. However, well $\mathrm{D}$ contains $\gamma$-u protein: this has reacted with the whole antiserum from $A$, but not with the absorbed antiserum from $C$. The band between wells $B$ and $D$ is due to 7S $\gamma$-globulin from $B$, reacting with the excess antibody present in $\mathrm{D}$. It does not give an ideal "reaction of identity" with the adjacent two 7S $\gamma$-bands, because the free antibody in $D$ is in low concentration.

terlony plate, two bands of precipitate formed (Figure 3 , reaction between wells $\mathrm{A}$ and $\mathrm{B}$ ). That nearer the antigen well was straight, and readily gave a reaction of identity with the $7 \mathrm{~S}$ $y$-globulin of plasma (3). The other band, due to $\gamma-\mathrm{u}$ protein, was concave to the antiserum well and, with some antisera, appeared as two approximately parallel bands. It is apparent from Figures 3 and 6 that $\gamma$-u protein possesses some, but not all, of the antigenic determinants of 7S $\gamma$-globulin.

Figure 4 shows that $\gamma$-u protein gives, on an Ouchterlony plate, a reaction of partial identity with both of the Bence Jones protein antigenic types recognized by rabbit antisera. The positions of spurs suggest that it possesses all those $\gamma$-globulin determinants possessed by Bence Jones proteins. This is confirmed by the fact that, after absorption with $\gamma-\mathrm{u}$ protein, the antiserum reacted with neither type of Bence Jones protein. Further, $\gamma$-u protein apparently has no other $\gamma$-globulin determinants, for it failed to react with the antiserum after the latter had been absorbed with Bence Jones protein of both antigenic types (Figure 3 , reaction between wells $B$ and $C$ ). These immunochemical findings are summarized in Figure 5 , which indicates the minimal number of determinants by which the results are explicable.

Gamma-u protein could not be divided into two discrete fractions corresponding to the two Bence jones antigenic types. When reacted in antibody excess with antiserum absorbed with only one type of Bence Jones protein, no residual $\gamma$ - $u$ protein could be detected in the supernatant by a precipitin test employing whole antiserum. Large amounts of absorbed antiserum were required (especially after absorption with a type $2^{1}$ Bence Jones protein), so that small amounts of unpre-

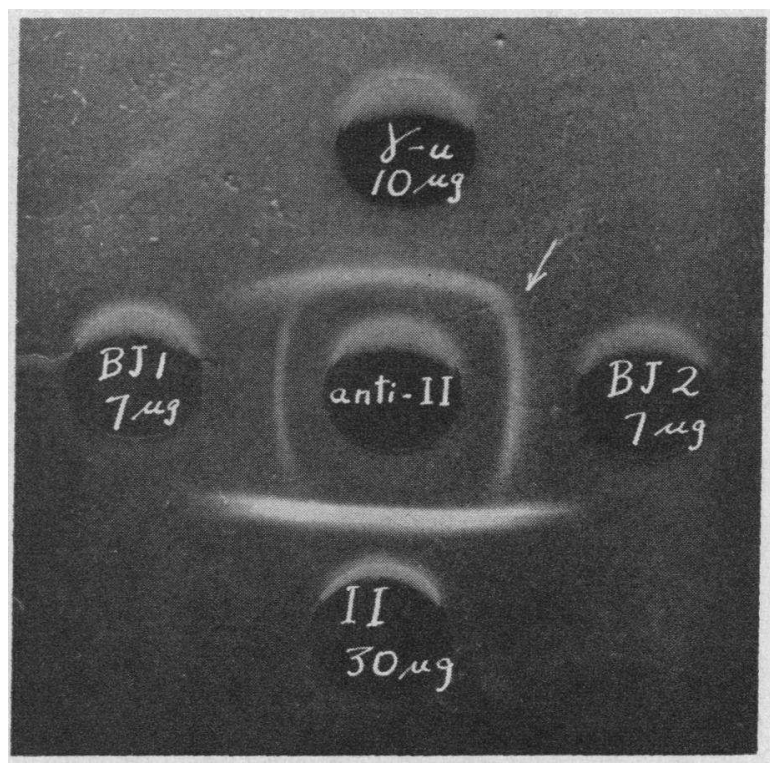

Fig. 4. Antigenic structure of gamma-U protein; A COMPARISON WITH THE TWO ANTIGENIC TYPES OF BENCE JoNES PROTEINS. The arrow marks the position of a faint spur, not apparent in the photograph, prolonged from the $\gamma$-u band past the BJ2 band. This spur was always weak, and was sometimes not apparent.

1 The numbering of the Bence Jones antigenic types is arbitrary; its relationship to designations used by previous authors is unknown. 


\section{S GAMMA GLOBULIN}

\section{CAMMA-U PROTEIN}

\section{BENCE JONES PROTEINS Antigenic type 1}

\section{BENCE JONES PROTEINS Antigenic type 2}

Fig. 5. Distribution of DEterminants Recognized BY RABBIT ANTISERUM TO HUMAN PLASMA GAMMA GLOBULINS. The determinants shown represent the minimum number by which immunochemical results are explicable.

cipitated $\gamma-\mathrm{u}$ protein would have been difficult to detect. The result therefore does not eliminate the presence of small amounts of $\gamma$ - $u$ protein possessing the determinants of only a single Bence Jones antigenic type, but it suggests that this is not the case for at least the greater part of the $\gamma$-u protein.

When heated at a protein concentration of $4 \mathrm{mg}$ per $\mathrm{ml}$, the DEAE-cellulose effluent showed reactions typical of a solution of Bence Jones protein (12). At $\mathrm{pH} 5$ and ionic strength 0.15 , partial precipitation occurred after 5 minutes at $55^{\circ} \mathrm{C}$.

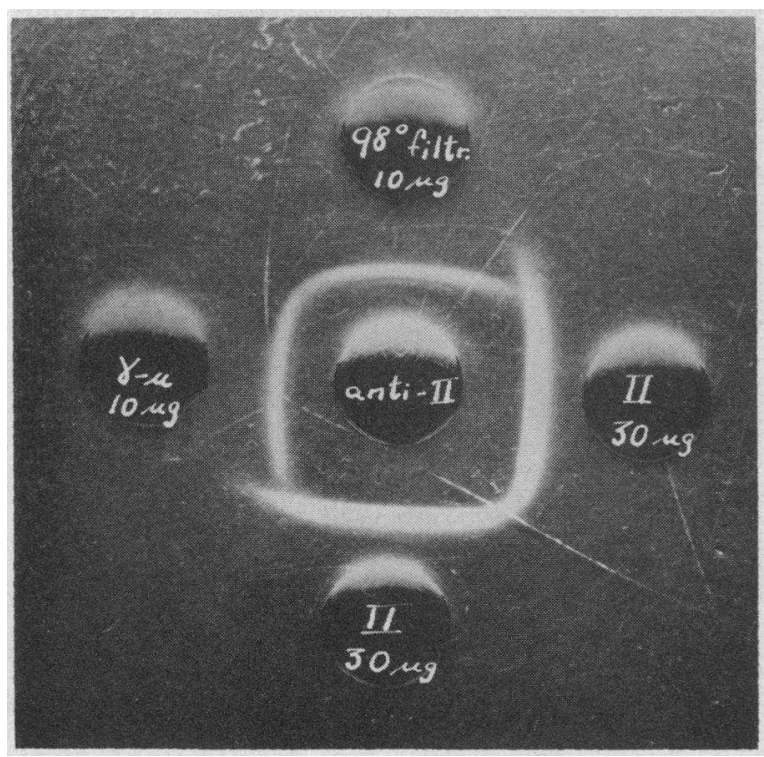

Fig. 6. Comparison OF GamMa-U PROTEIN WITH A FILTRATE OBTAINED AT $98^{\circ} \mathrm{C}$ FROM URINARY GAMMA-RELATED PRoteins (DEAE-CELlulose EFfluent). The two preparations are indistinguishable by precipitin reaction on an Ouchterlony plate.
When only the $\mathrm{pH}$ was varied, precipitation occurred to a lesser extent at $\mathrm{pH} 6.5$, and not at $\mathrm{pH}$ 7.4. The $55^{\circ} \mathrm{C}$ precipitate was collected by centrifugation, washed at room temperature, suspended in the pH 5 buffer, heated in a boiling water bath for 5 minutes, and then filtered in an oven at $98 \pm 4^{\circ} \mathrm{C}$. The filtrate contained about $0.5 \mathrm{mg}$ protein per $\mathrm{ml}$. It became turbid on cooling if the cooling was very slow ( 1 hour or more to reach $40^{\circ} \mathrm{C}$ ) and would then again become clear when returned to the boiling water bath.

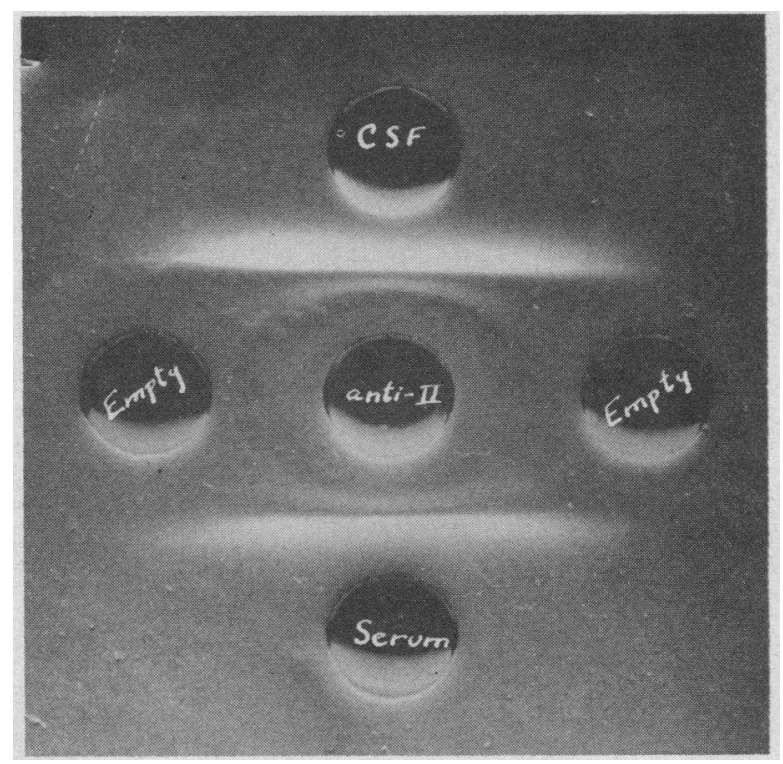

Fig. 7. Reactions With aNTI-II SERUM OF PROTEIN FRACTIONS OBTAINED FROM SERUM AND CEREBROSPINAL FLUID. The fractions represent those whose delivery from a Sephadex G-75 column was retarded: see text and Table I.

Filtrates obtained at $98^{\circ} \mathrm{C}$, either directly from column effluent or from a suspension of the $55^{\circ} \mathrm{C}$ precipitate yielded by this effluent, were examined by precipitin reaction on an Ouchterlony plate. In each the protein in solution was immunochemically identical with $\gamma$-u protein and had a similar diffusion coefficient (Figure 6). This suggests that $\gamma$-u protein is responsible for the precipitate forming at $55^{\circ} \mathrm{C}$, and that its denaturation on being heated is at least partially reversible (3).

The presence of $\gamma$ - $u$ protein in serum and cerebrospinal fluid. When serum or CSF reacts with anti-II serum on an Ouchterlony plate, no line corresponding in position and curvature to the $\gamma-\mathbf{u}$ 
line forms. Only a straight 7S $\gamma$-line is seen and, in the case of serum, an inconstant 19S $\gamma$-line concave to the antigen well. This need not mean that $\gamma-\mathrm{u}$ protein is absent; it indicates only that its concentration relative to that of $7 \mathrm{~S} \gamma$-globulin is below a certain value. ${ }^{2}$ Preliminary experiments showed that, when passed through a Sephadex G-75 column, both Bence Jones proteins and $\gamma$-u protein move slightly, but significantly, more slowly than does 7S $\gamma$-globulin. Accordingly, serum and CSF were each put through the column previously described, and the effluent at different stages was tested by precipitin reaction with anti-II serum on an Ouchterlony plate. The effluents following those containing the bulk of the protein had to be concentrated by dialysis against polyvinylpyrrolidone before being tested. In each case the later effluents gave a band of precipitate similar to that given by $\gamma$-u protein (Figure 7 ; experimental detail in Table I). These bands also gave reactions of identity with a $\gamma$-u precipitate band. Thus both serum and CSF appear to contain protein resembling $\gamma-\mathrm{u}$ protein in antigenic structure and molecular size.

Radioisotopic investigation of the origin of urinary $\gamma$-related proteins. As previously stated, two subjects were injected with radioiodinated plasma $\gamma$-globulins, and their urinary proteins were prepared from two collections: urine passed from 25 to 72 and from 73 to 120 hours after injection. The fall in serum radioactivity followed the usual decreasing exponential rate observed for $\gamma$-globulins (14), the half-lives stabilizing at 20 and 19 days after the fifth day (Figure 8).

It was thought that the only rapid and certain method of separately obtaining the urinary $7 \mathrm{~S}$ $\gamma$ - and $\gamma$-u proteins in high yield was immunochemical precipitation. The following procedure was therefore adopted.

1) To an aliquot of the 48-hour urinary protein, dissolved in buffered saline, was added an excess of anti-II serum which had previously been absorbed, at the equivalence points, with Bence

2 When an antiserum reacts with its homologous antigen on an Ouchterlony plate, the presence of a cross-reacting antigen (containing some but not all of the determinants of the system), admixed with the homologous antigen, will not be apparent unless the ratio (cross-reacting antigen:homologous antigen) exceeds a certain minimum (13).
TABLE I

Fractionation of serum and CSF proteins on Sephadex G-75

\begin{tabular}{|c|c|c|}
\hline Sample applied & $\begin{array}{l}\text { Void } \\
\text { volume }\end{array}$ & $\begin{array}{l}\text { Effluent examined on } \\
\text { Ouchterlony plate }\end{array}$ \\
\hline $\begin{array}{l}\text { Fresh } \\
\quad \text { serum, } 10 \mathrm{ml}\end{array}$ & $\begin{array}{l}m l \\
25\end{array}$ & $\begin{array}{l}21-40 \mathrm{ml} \text { inclusive } \\
\text { after void volume; } \\
\text { conc. } 5 \text {-fold }\end{array}$ \\
\hline $\begin{array}{l}\text { CSF, } \\
\text { concentrated } \\
16-\text { fold, } 5 \mathrm{ml}\end{array}$ & 26 & $\begin{array}{l}\text { 8-15 } \mathrm{ml} \text { inclusive } \\
\text { after void volume; } \\
\text { conc. } 3 \text {-fold }\end{array}$ \\
\hline
\end{tabular}

Jones proteins of both antigenic types. ${ }^{3}$ This step precipitated only the 7S $\gamma$-globulin, and it is illustrated by the reaction occurring between wells $\mathrm{B}$ and $\mathrm{C}$ in Figure 3.

2) The $\gamma$-u protein was then precipitated from the supernatant by unabsorbed antiserum, in the equivalence or antibody excess zone. Because of the large volume of antiserum required, the antibodies were used in fivefold concentrated solution, having been precipitated from the serum by dialysis against 0.4 saturated ammonium sulfate. This second step is illustrated by the reaction occurring between wells D and A in Figure 3 .

Washed specific precipitates were dissolved in biuret reagent and their radioactivity and total protein content estimated. Amounts of antigen

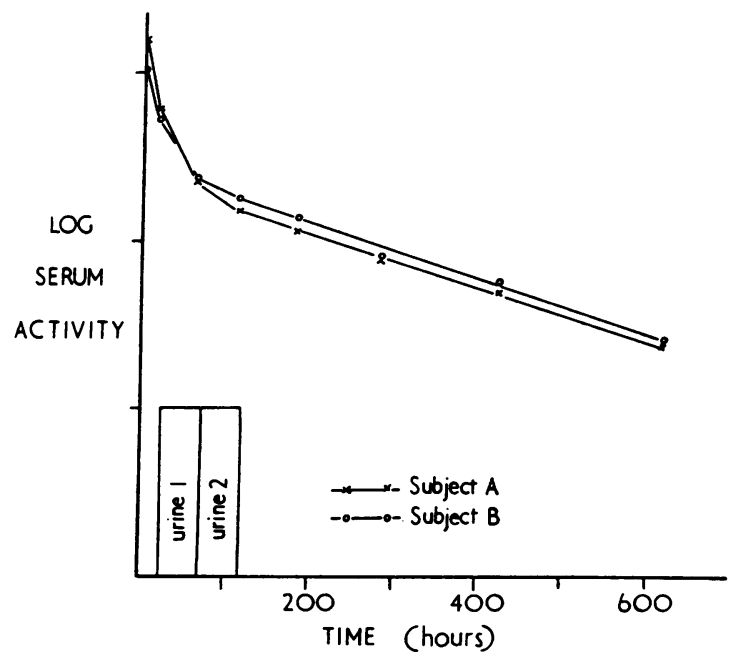

Fig. 8. Serum radioactivity after injection of I $^{181}$ LABELED PLASMA GAMMA GLOBULINS. Half-lives after the fifth day: A, 20 days; $B, 19$ days.

3 The more straightforward procedure of absorption with $\gamma$-u protein was not adopted because it was diffcult to obtain enough of it of acceptable purity. 
TABLE II

Specific activities of urinary and plasma proteins after injection of $I^{131-l a b e l e d ~ p l a s m a ~ \gamma-g l o b u l i n s *}$

\begin{tabular}{|c|c|c|c|c|c|c|c|c|c|}
\hline \multirow[b]{2}{*}{ Subject } & \multirow{2}{*}{$\begin{array}{l}\text { Time of } \\
\text { urine } \\
\text { collection } \\
\text { (incl. } \\
\text { after } \\
\text { inject.) }\end{array}$} & \multicolumn{3}{|c|}{ 7S $\gamma$-globulin } & \multicolumn{3}{|c|}{$\boldsymbol{\gamma}$-u protein } & \multirow[b]{2}{*}{$\begin{array}{c}\text { Activity } \\
\text { not } \\
\text { precip. }\end{array}$} & \multirow{2}{*}{$\begin{array}{c}\text { Specific } \\
\text { activity, } \\
\text { plasma } \\
7 \mathrm{~S} \\
\gamma \text {-glob. } \ddagger\end{array}$} \\
\hline & & $\begin{array}{c}\text { Activity, } \\
\text { immune } \\
\text { precip. }\end{array}$ & $\begin{array}{c}\text { Antigen } \\
\text { in } \\
\text { precip. } †\end{array}$ & $\begin{array}{l}\text { Specific } \\
\text { activity, } \\
\text { antigen }\end{array}$ & $\begin{array}{l}\text { Activity, } \\
\text { immune } \\
\text { precip. }\end{array}$ & $\begin{array}{c}\underset{\text { Antigen }}{\text { Antip. }} \\
\text { precip }\end{array}$ & $\begin{array}{l}\text { Specific } \\
\text { activity, } \\
\text { antigen }\end{array}$ & & \\
\hline & hrs & $c p m$ & $m \boldsymbol{g}$ & $c m p / m g$ & $c p m$ & $m g$ & $c p m / m g$ & $c p m$ & $c p m / m g$ \\
\hline A & $\begin{array}{l}25-72 \\
73-120\end{array}$ & $\begin{array}{l}1,950 \\
1,130\end{array}$ & $\begin{array}{l}2.0 \\
1.8\end{array}$ & $\begin{array}{r}1,000 \\
600\end{array}$ & $\begin{array}{r}124 \\
23\end{array}$ & $\begin{array}{l}2.9 \\
2.5\end{array}$ & $\begin{array}{r}40 \\
9\end{array}$ & $\begin{array}{r}375 \\
74\end{array}$ & $\begin{array}{l}\mathbf{5 7 0} \\
\mathbf{3 8 0}\end{array}$ \\
\hline B & $\begin{array}{l}25-72 \\
73-120\end{array}$ & $\begin{array}{r}1,560 \\
595\end{array}$ & $\begin{array}{l}1.3 \\
1.6\end{array}$ & $\begin{array}{r}1,000 \\
400\end{array}$ & $\begin{array}{l}85 \\
28\end{array}$ & $\begin{array}{l}3.2 \\
2.6\end{array}$ & $\begin{array}{l}30 \\
10\end{array}$ & $\begin{array}{l}452 \\
140\end{array}$ & $\begin{array}{l}520 \\
310\end{array}$ \\
\hline
\end{tabular}

* The figures given refer to one-third of the urinary protein excreted during the indicated 48-hour periods. Another third of each 48-hour urinary protein solution was used as a duplicate for the precipitation of $7 \mathrm{~S} \gamma$-globulin. The supernatants from the duplicates (one of which provided the contents of well $D$, Figure 3) were checked to ensure that precipitations of $7 \dot{S} \gamma$-globulin were occurring in the antibody excess zone.

$\dagger$ Read off previously prepared quantitative precipitin curves. The figures for $\gamma$-u protein must be regarded with reserve.

$¥$ At the middle of the corresponding urine collection period, with counts corrected to the times at which the urine samples were counted. Obtained from the serum radioactivity curve, and (on the basis of normal electrophoretic patterns) a plasma $7 \mathrm{~S} \gamma$-globulin concentration assumed of $11 \mathrm{mg}$ per $\mathrm{ml}$ for each subject.

in the precipitates were read off previously prepared quantitative precipitin curves. These estimates are approximate, and so specific activities of the urinary proteins are given to only one significant figure. Results are shown in Table II. The urinary 7S $\gamma$-globulin had specific activities greater than those of its plasma counterpart, and accounted for 74 to 92 per cent of the total radioactivity of the urinary proteins; $\gamma$ - $u$ protein had negligible specific activities.

\section{DISCUSSION}

The broad distributions of electrophoretic and solubility properties shown by the urinary $\gamma$-related proteins are well known for the same group in plasma $(14,15)$. The urinary proteins present the additional complication of being admixed with large amounts of other proteins throughout their electrophoretic path. These facts have caused great difficulty in obtaining well purified preparations in reasonable yield. Another possible, complicating factor in any physicochemical study of these proteins is urinary proteolytic activity, although at least $7 \mathrm{~S} \gamma$-globulin does not seem overtly susceptible to this $(2,3)$.

The conclusion that much of the protein in DEAE-cellulose and electrophoretic preparations is not $\gamma$-related is subject to some reservation because of the inherent variability of antisera. However, six rabbits provided the antiserum used in these experiments, somewhat reducing the chance of its lacking antibodies to some determinants simply because of random variation. Nor does it seem likely that much of the urinary protein of $\gamma$-electrophoretic mobility consists of breakdown products of plasma $\gamma$-globulins in which all antigenic structure has been lost. For, in the isotopic study, little radioactivity remained in the supernatant after the 7S $\gamma$-globulin had been precipitated.

The finding that only 7S $\gamma$-globulin in urine is significantly labeled while radioiodinated $\gamma$-globulins are in the plasma is quite at variance with reports of two previous, similar experiments $(1,2)$. These state that, in the 24 hours after injection of ${ }^{131}$-labeled plasma $\gamma$-globulins, the total urinary protein of $\gamma$-electrophoretic mobility had a specific activity comparable with that of the same fraction in serum. From this it was concluded that the low molecular weight urinary proteins represent breakdown products of the plasma proteins. The cause of the discrepancy is not apparent. Because of many differences in experimental detail, the results cannot readily be compared. In the present experiment, urine from the first 24 hours was not used because of the possibly early clearance of abnormal low molecular weight material, either injected or resulting from breakdown of molecules altered during handling. Two incidental findings may also be relevant: there was somewhat more (immunologically defined) 7S $\gamma$-globulin in the urine than was usual, and this had a specific activity actually higher than that of its serum counterpart.

It must be emphasized that the specific activities reported for $\gamma$-u protein in this experiment are 
possibly subject to large error. Estimation of the amounts present involved the use of only a rough precipitin curve and assumed that $\gamma$ - $u$ protein was the only antigen in the precipitates. It is possible that some soluble complexes of Bence Jones proteins with antibody were precipitated simultaneously. Nevertheless, the true specific activities of $\gamma$-u protein must have been much lower than those of $7 \mathrm{~S} \gamma$-globulin, simply because little radioactivity remained in the supernatants after the latter had been precipitated. The experiment therefore strongly suggests that $\gamma$ - $\mathfrak{u}$ protein is not a breakdown product of plasma $\gamma$-globulins.

It is probable that some plasma $7 \mathrm{~S} \gamma$-globulin molecules enter urine via the glomeruli and account for the straight band of precipitate found on Ouchterlony plates, the leading peak in the ultracentrifugal patterns, and the bulk of the protein radioactivity in the isotopic study. The sedimentation velocities found, although uncorrected for protein concentration, are lower than might be expected in an unbiased sample of plasma $7 \mathrm{~S}$ $\gamma$-globulin. However, the latter shows a distribution of sedimentation constants (16), and glomerular filtration may well favor components with the lower values.

Unlike most Bence Jones proteins, $\gamma$-u protein is overtly heterogeneous upon electrophoresis. The continuous distribution of mobilities illustrated in Figure 1 resembles the range found for mobilities of individual Bence Jones proteins (12). Curvatures of the precipitin lines on Ouchterlony plates (17), and ultracentrifugal findings, are consistent with a molecular weight of $\gamma$ - $\mathrm{u}$ protein within the range $(24,000$ to 90,000$)$ reported for Bence Jones proteins (18). Further resemblances to Bence Jones proteins may be enumerated: precipitation at a low temperature, with the $\mathrm{pH}$ dependence which has been stressed by Putnam (12); unusually high solubility near the boiling point of water ; apparent reversibility of heat denuration (3); and antigenic structure. Finally, again like Bence Jones proteins (19), it does not appear to be a breakdown product of larger molecules to which it is related.

An analogy is apparent between relationships of 7S $\gamma$-globulin to serum myeloma proteins on the one hand, and relationships of $\gamma-\mathrm{u}$ protein to Bence Jones proteins on the other. In the former case, the normal proteins are electrophoretically heterogeneous, the pathological proteins usually homogeneous; and the pathological proteins possess some, but not all, of the antigenic determinants of the normal proteins $(12,20,21)$. From the known properties of Bence Jones proteins (12), and results presented here, the same relationships are seen to hold in the latter case.

Much information is yet required about the relationship of $\gamma$ - $u$ protein to Bence Jones proteins. The antigenic subdivision of the latter, shown in Figure 5, is much simpler than are classifications suggested by other criteria. Horse antisera recognize three antigenic types $(22,23)$. Other methods, in particular electrophoretic mobility, discriminate further between the individual proteins, and it has been suggested $(24,25)$ that perhaps no two are exactly alike. Most of the data in this paper are compatible with the hypothesis that $\gamma$-u protein consists of a multitude of molecular types, each one of which resembles a single Bence Jones protein. If this be so, however, it should be possible to precipitate some, but not all, of the $\gamma$-u protein with an antiserum that would precipitate only one antigenic type of Bence Jones protein. To date it has not been possible to demonstrate this.

Gamma-u protein is also of interest as a possible precursor of larger $\gamma$-globulin molecules. Subunits of 7S $\gamma$-globulin, probably linked by disulfide bonds, have recently been described (26). It will be interesting to compare these with $\gamma$-u protein.

\section{SUMMARY}

The urinary proteins that are antigenically related to plasma $\gamma$-globulins have a broad electrophoretic distribution and may account for only about one-third of the urinary protein of $\gamma$-electrophoretic mobility.

These proteins are divisible into two groups on the basis of molecular size. The larger molecules appear to be 7S $\gamma$-globulin, derived from the corresponding protein of plasma. The smaller molecules (" $\gamma$-u protein") resemble Bence Jones proteins in molecular size, thermosolubility, and antigenic structure.

As defined by reactions with rabbit antiserum to plasma $\gamma$-globulins, the antigenic structure of $\gamma$-u protein appears to include all determinants repre- 
sented on the different antigenic types of Bence Jones proteins, and no other determinants.

Material resembling $\gamma$-u protein in molecular size and antigenic structure has been identified in serum and cerebrospinal fluid.

An isotopic study suggested that $\gamma$ - $u$ protein is not a breakdown product of larger plasma $\gamma$-globulin molecules.

\section{ACKNOWLEDGMENTS}

I am indebted for advice and assistance to C. R. B. Blackburn, G. M. Kellerman, W. J. Hensley, M. B. Smith, H. L. Webster, W. F. Green, Miss Toni Gale, and Miss Joan Back. The advice of J. McRae for the radioactive study was especially valuable.

\section{REFERENCES}

1. Webb, T., Rose, B., and Sehon, A. H. Biocolloids in normal human urine. II. Physiochemical and immunochemical characteristics. Canad. J. Biochem. 1958, 36, 1167.

2. Franklin, E. C. Physiochemical and immunologic studies of gamma globulins of normal human urine. J. clin. Invest. 1959, 38, 2159.

3. Stevenson, G. T. Detection in normal urine of protein resembling Bence Jones protein. J. clin. Invest. $1960,39,1192$.

4. Schachman, H. K. Ultracentrifugation, diffusion, and viscometry in Methods in Enzymology, S. P. Colowick and N. O. Kaplan, Eds. New York, Academic Press, 1957, vol. 4, p. 32.

5. Kabat, E. A., and Mayer, M. M. Experimental Immunochemistry. Springfield, Ill., Thomas, 1948.

6. Bayne-Jones, S., and Wilson, D. W. Immunological reactions of Bence-Jones proteins; II. Differences between Bence-Jones proteins from various sources. Bull. Johns Hopk. Hosp. 1922, 33, 119.

7. Hektoen, L., and Welker, W. H. Immunological differences of crystalline Bence-Jones proteins. Biochem. J. 1940, 34, 487.

8. Korngold, L., and Lipari, R. Multiple-myeloma proteins; III. Antigenic relationship of Bence Jones proteins to normal gamma-globulin and multiplemyeloma serum proteins. Cancer 1956, 9, 262.

9. Kunkel, H. G., and Trautman, R. Zone electrophoresis in various types of supporting media in Electrophoresis, M. Bier, Ed. New York, Academic Press, 1959, p. 225.

10. Porath, J., and Flodin, P. Gel filtration: A method for desalting and group separation. Nature (Lond.) 1959, 183, 1657.
11. Talmage, D. W., Baker, H. R., and Akeson, W. The separation and analysis of labelled antibodies. J. infect. Dis. 1954, 94, 199.

12. Putnam, F. W. Aberrations of protein metabolism in multiple myeloma; interrelationships of abnormal serum globulins and Bence-Jones proteins. Physiol. Rev. 1957, 37, 512.

13. Ouchterlony, Ö. Diffusion-in-gel methods for immunological analysis. Progr. Allergy 1958, 5, 1.

14. Porter, R. R. $\gamma$-Globulin and antibodies in The Plasma Proteins, F. W. Putnam, Ed. New York, Academic Press, 1960, vol. 1, p. 241.

15. Williams, C. A., Jr., and Grabar, P. Immunoelectrophoretic studies on serum proteins; human gamma globulin. J. Immunol. 1955, 74, 404.

16. Cann, J. R. Ultracentrifugal properties of human $\gamma$-globulins prepared by electrophoresis convection. J. Amer. chem. Soc. 1953, 75, 4213.

17. Korngold, L., and van Leeuwen, G. The effect of the antigen's molecular weight on the curvature of the precipitin line in the Ouchterlony technic. J. Immunol. 1957, 78, 172.

18. Rundles, R. W., Cooper, G. R., and Willett, R. W. Multiple myeloma. IV. Abnormal serum components and Bence Jones protein. J. clin. Invest. 1951, 30, 1125.

19. Putnam, F. W., and Miyake, A. Proteins in multiple myeloma. VIII. Biosynthesis of abnormal proteins. J. biol. Chem. 1958, 231, 671.

20. Deutsch, H. F., Morton, J. I., and Kratochvil, C. H. Antigenic identity of hyperglobulinemic serum components with proteins of normal serum. J. biol. Chem. 1956, 222, 39.

21. Korngold, L., and Lipari, R. Multiple-myeloma proteins. I. Immunological studies. Cancer 1956, 9, 183.

22. Burtin, P., Hartmann, L., Fauvert, R., and Grabar, P. Etudes sur les proteines du myélome. I. Etude critique des techniques d'identification de la protéine de Bence-Jones et de leur valeur diagnostique. Rev. franç. Et. clin. biol. 1956, 1, 17.

23. Scheidegger, J. J., and Buzzi, C. Etude immunoélectrophorétique des gamma-globulines. Rev. franç. Et. clin. biol. 1957, 2, 895.

24. Putnam, F. W. Abnormal serum globulins in The Plasma Proteins, F. W. Putnam, Ed. New York, Academic Press, 1960, vol. 2, p. 345.

25. ten Thije, O. J. Urinary and serum proteins in myelomatosis. Acta med. scand. 1956, 153, 253.

26. Edelman, G. M., and Poulik, M. D. Studies on the structural units of the $\gamma$-globulins. J. exp. Med. 1961, 113, 861. 